\title{
The impact of work passion on work performance: the moderating role of P-O fit and meaningfulness of work
}

\author{
IKA INDRIASARI ${ }^{1}$ and NONI SETYORIN| ${ }^{1}$
}

${ }^{1}$ Management Department, Economics and Business Faculty, Universitas PGRI Semarang

\begin{tabular}{ll}
\hline Abstract & Our study aims to analyze the impact of auditor's work passion on their performances, with \\
meaningfulness of work and person organization fit (PO-fit) as moderating variables. \\
Auditor, as a profession associated with assurance of compliance with their clients, highly \\
requires good work passion to increase their spirit, avoid them from work saturation and \\
improve their work quality. Therefore, our study expected that work passion positively affect \\
work performance. Furthermore, meaningfulnes work and PO-fit were also expected to have \\
moderating effect on the relationship of work passion on work performance. The results of \\
regression and moderated regression analysis (MRA) on 87 samples collected from \\
accoutants working in public accountant firm in Java, Indonesia, suggest that work passion \\
has a positive effect on work performance. The result also shows that meaningfulnes was \\
supported as a moderator on the relationship between work passion and work performance. \\
However, our prediction that PO-fit could be a moderator in the effect of work passion on job \\
performance of auditor was not supported.
\end{tabular}

Keywords

auditor; work passion; meaningfulness of work, person organizational fit; work performance

\section{INTRODUCTION}

The dynamics and forces at the workplace mainly compel the organizations to be more creative in finding solutions over many problems (Srivastava, 2012). This should be supported by the awareness of top managers to start recognizing other supporting factors besides technology, capital and products, as they can easily be bought and imitated by competitors. On this ground, top managers should make human resources a crucial factor to be turned into the company's competitive advantage (Srivastava, 2012).

Understanding the importance of human resources as a supporting factor for the success of the company will certainly impact on the significance of employee competence and expertise. Establishing employee competence and expertise is made possible by way of building up work passions. It is undeniable that every company will surely want its employees to be passionate at work. This is because passion will generate more productivity and better strength to face any challenges (Havard Business Review, 2011).

Work passion is defined as pleasure, the willingness to struggle even more, and laboriously (Astakhova \& Porter, 2015). Passion is also defined as a strong will to an activity or work which leads an individual to be willingly devote his time, energy, and mind (Forest et al., 2010). Employees with high work passion are regarded as the franchise talent required by the organization because the work passion can drive employees to be more productive, more efficient, and more diligent enabling them to be a valuable asset of the company (Srivasta 2012).

Auditor, as a profession associated with assurance of compliance with the client's financial statements, highly requires good work passion. Internal auditors and external auditors of the company are required to have a good passion to encourage its performance. Auditor performance requires enough knowledge and experience to be able to perform their duties properly. By having good work passion, the auditor is expected to increase their spirit, avoid them from work saturation, and improve their work quality. An old study from Brayfield and Crockett (1955) in Srivastava (2012) mentions that if an employee is satisfied with his job, the chances of changing work are lower. So far, the auditor's work has been used as an early 
career choice for young accountants seeking permanent employment or mere working experience. Without passion for the job, auditing can become an easily abandoned profession once someone gained other more comfortable or more satisfactory professions. Work passion is deemed as a positive concept, no wonder that according to Yahui and Jian (2015) it is a highly studied issue. Harmonious passion is said to have a positive influence on one's physical health, psychological well being, self esteem, positive emotions, and creativity. The passion crusade is also said to have an impact on job satisfaction, commitment, performance, and burnout (Burke and Fiksenbaum 2009). et al. A study (2011) on the effect of work passion on work performance articulates that there is a growing need for more exploration on this topic because there are only few researches to address this issue.

Work performance is an important factor for the company. Rotundo and Sackett (2002) in Chien, Lawler, and Uen (2010) mentioned that work performance is a concept as an action and behavior under individual control and may be used as a contribution to corporate goals. This is because the improvement of employee performance will have a positive impact on the company's success. On this basis, the research is focused on the impact of work passion on the employees' work performance.

Other studies have also revealed that the effect of work passion and work performance relationships remains inconsistent (Astakhova \& Porter, 2015). Some researchers say the work passion relationship to work performance is positive but other researchers say otherwise. Based on the inconsistency of the research, there is a demand for using moderating role that connects between work passion and work performance.

Passion tends to be an employee's needs associated with the development of competence, association and autonomy. The first moderator in this study was PersonOrganization Fit. Person-Organization Fit is known to be affecting the fundamental human needs (Greguras \& Diefendorff, 2009). P-O fit is often formulated as an appropriateness between employee values and organizational values (Kristof, 1996). Employees who have a value system in accordance with the value of the organization will be easier to get job satisfaction (Greguras and Diefendorff, 2009). Based on the above explanation, this research will use Person-Organization fit as moderator.

The second moderator used in this study is the meaningful of work. Meaningful of work relates to well being and work related outcomes. Steger et al. (2010) describes the key principles of meaningfulness of work consisting of three main aspects: (1) positive meaning at work, the subjective meaning that a person's work has a meaning for his personality; (2) the meaning making through work, the extent to which the work helps people understand the world and contribute to personal growth; and (3) the greater good motivation, the belief that one's work will have another positive effect on the other. On this ground, this research will use meaningful work as a second moderator. Based on the obtained exposure and gaps, the researcher tries to fill the research gap by submitting a research entitled "The Impact of Work Passion to Work Performance with P-O fit and Meaningfulness of Work as Moderator".

\section{LITERATURE REVIEW AND HYPOTHESES DEVELOPMENT}

In the last few years, many studies have been addressed work passion. Smith (2008) states that work passion is an emotional employee designed to cultivate a strong response from the subject through an impression of extreme things, such as the offense or sadness that a person has gone through. Passion is defined as a strong tendency toward an activity, like a job favored by a person, so that in that work he devotes considerable time and energy. This passion is connected with a variety of attitudes and outputs that are cognitive (Forest et al, in Astahkhova and Porter, 2015).

Work passion is classified into two categories, that are harmonious and obsessive (Valerand et al., 2003). A harmonious passion derives from the internalization of the self to a preferred activity, in one's identity or one's willingness to be attached to an activity and to integrate it with other aspects of life. On the contrary, an obsessive passion is the result of a controlled internal self-control of an activity that is driven by intra- or individual emphasis on a need, such as the need for self-actualization, acceptance of the environment or respect and may be in conflict with other life activities, which become a kind of fixed price for a person (Vallerand, 2010; 103). 
Vallerand et al (2007) found that work passion produces activities leading to a person's performance. Vallerand (2003) uses self-determination theory to explain the process underlying individual passion for a preferred activity. The study concluded that both the harmony and the obsessive types of passion arise from the internalization of a favored activity into one's self identity.

\section{Impact of work passion and work performance}

Conservation of Resources theory stated by Hobfoll (1989) provides a contextual explanation that the individual will strive to create, protect, and preserve his/her resources. Resources has an important role to play in individual reactions (Hobfoll, 1989). The resources referred to in the theory are goals, personal characteristics, or strengths possessed or derived due to an achievement or protection of a source of value (Hobfoll, 2001).

Based on the theory, a person with a high work passion level will love his work more which eases him to invest his time and energy (Vallerand, 2008). This will have an impact on the improvement of one's self esteem (Baumeister et al., 2003), which will cause the individual to feel the need to improve his / her work performance.

H1: work passion has a positive impact on work performance

\section{Work passion and work performance with meaningful work as moderator}

Vallerand (2008) states that a person with a high work passion will more easily love his work which eases him to invest his time and energy. This is because someone with a high work passion will feel that his job is an inner call of his soul (Vallerand and Houlfort, 2003).

This is supported by the opinion of Michaelson et al. (2014) that the meaningfulness of work can facilitate the search for psychosocial behavior and psychological experiences. Meaningfulness of work can also make employees do the job with full appreciation. Employees work by involving the cognitive and affective aspects so that with appreciation will have an impact on the results of his work. Individuals who achieve meaningfulness of work will have positive outcomes for the organization
(Geldenhuys, Profit, and Venter, 2014). Individuals who perceive their work as meaningful will do their work with full of passion and dedication.

H2: Meaningfulness of work moderates the effect of work passion on work performance. The higher the meaningful of work the employee has, the stronger the relation between work passion to work performance.

\section{Work passion and work performance with P-O fit as moderator}

Work passion is something that can meet employee satisfaction both in terms of competence and autonomy (Astakhova \& Porter, 2015). Besides, the employee's compatibility with the work environment is also another required basic need (Greguras \& Diendorff, 2009). The connection between the need for passion and work compatibility is a trigger factor for a person in the workplace.

It is in line with the self determination theory explaining that each individual must have the inherent motivation in him which drives him to perform various activities in social life. Based on the theory, work passion is one of internal motivation that encourages one to give the best in the workplace. Someone with good work passion and highcompatibility value with an organization will find it easier to improve his performance.

H3: $P-O$ fit moderates the relationship between work passion and work performance. The higher the $P-O$ fit the employees have, the stronger the relationship between work passion and work performance.

\section{METHODS}

This study uses online and offline survey to collect data. The questionnaire were validated by previous research and translated into the Indonesian language consisted of 32 item statements including 14 items representing work passion, 10 items representing the meaningfulness of work, 5 items representing work performance, and 3 items representing the person organization fit. 
Table 1. Hypotheses Test

\begin{tabular}{|c|c|c|c|c|}
\hline Variable & Model 1 & Model 2 & Model 3 & Model 4 \\
\hline \multicolumn{5}{|l|}{ Control variable } \\
\hline Gender & ,004 &,- 082 & ,078 &,- 082 \\
\hline Age & ,288 &, 036 &, 181 & 033 \\
\hline Education &,- 038 &, 163 &,$- 253^{*}$ &, 155 \\
\hline Work tenure &, 121 &, 142 &,- 132 &, 145 \\
\hline \multicolumn{5}{|l|}{ Independent variable } \\
\hline Work passion & &, $663^{*}$ & ,396* & ,700 \\
\hline \multicolumn{5}{|l|}{ Moderating variable } \\
\hline Meaningfulness of work & & & 276 & - \\
\hline Person Organization fit & & & - &,- 089 \\
\hline \multicolumn{5}{|l|}{ Interaction effect } \\
\hline WP X MW & & &, $217^{*}$ & - \\
\hline WP X PO & & & - & 0,60 \\
\hline R2 & 0,138 & 0,492 & 0,636 & 0,496 \\
\hline$\Delta \mathbf{R} 2$ & 0,096 & 0,461 & 0,604 & 0,457 \\
\hline $\mathbf{F}$ & $3,273^{*}$ & $15,687^{*}$ & $19,736^{*}$ & $11,118^{*}$ \\
\hline
\end{tabular}

The questionnaires were distributed since February 1, 2017 and May 21, 2017 to accountants working in public accounting firm and partly by using on line survey. The number of questionnaires distributed was around 120 questionnaires. Questionnaires returned and can be processed were 87 .

The selected respondents were characterized by age, sex, education level, and length of work. Based on the processed data the majority of respondents were men with S-1 education background. The most age range of the respondents was between 25-30 years. While the longest work was 1-3 years and $>5$ years.

\section{Measurements}

\section{Work passion}

Work passion is defined as a strong will to an activity or work which compels an individual to be willing to invest his time, energy, and mind (Forest et al., 2010). This variable was measured using 14 questions developed by Vallerand et al. (2003) ). It was measured using Likert scale type 5 point measurement scale, ranging from 1 (strongly disagree) to 5 (strongly agree). An example of a question item is "My work provides an unforgettable experience".

\section{Work Performance}

The variable was measured using 5 questions developed by Podsakoff and MacKenzie's (1989). This measurement was adopted because it reflected the meaningfulness of work. This variable was measured using Likert scale type 5 points measurement scale, ranging from 1 (strongly disagree) to 5 (strongly agree). One example of the meaningful work question items is that I always complete my task in accordance with company requirements.

\section{Meaningfulness of work}

The variable was measured using 10 items of questions developed by (MLQ; Steger et al., 2006). This measurement was adopted because it reflected the meaningfulness of work. This variable was measured using Likert scale type 5 points measurement scale, ranging from 1 (strongly disagree) to 5 (strongly agree). One example of a meaningful work question item is I have found a job that is able to give meaning to my life.

\section{Person-organization fit}

Person-organization fit was measured using 3 questions developed by Cable and DeRue's (2002). This variable was measured using Likert scale type 5 points measurement scale, ranging from 1 (strongly disagree) to 5 (strongly agree). An example item of personorganization fit question is the value of my life is in line with company value

\section{Control Variables}

The control variable is a variable that is controlled or made constant so that the relation of independent variable to the dependent variable is not influenced by outside factor which is not researched and 
can be examined more carefully (Gudono, 2012). The control variables in this study were education, age, gender, and work tenure.

\section{Data Analysis}

Companies often make use of regression analysis for corporate decision making. Regression analysis is not only used to solve simple problems but also complex problems (Hair et al, 2010). Regression tests are used when the researcher wants to determine the strength of the relationship (asymmetric) between the dependent variable and the independent variable (Gudono, 2012). Therefore, the purpose of regression testing is to predict one dependent variable from one or more independent variables.

Furthermore, the moderators were tested using moderated regression analysis. In line with Baron \& Kenny's explanation (1986) if the independent variables and moderation variables are continuous variables and the linear effects are linear, the approach should be to test moderated regression analysis. This approach was done by regressing $Y$ on $X, Z, X Z$. The effects of moderation can be seen in $X Z$. Meanwhile, as an attempt to avoid the multicolinearity between predictors and their interactions, the researchers centered the predictors to near zero and multiplied them in interaction forms (Aiken \& West, 1991 in Yperen \& Hagedoorn, 2003).

\section{RESULTS AND DISCUSSION}

We examine the hypotheses using regression test and Moderated Regression Analysis (MRA). Regression analysis is performed on hypotheses 1,2, and 3. MRA analysis is a hierarchically designed regression form to determine the relationship between two variables that are affected by the third variable or moderating variables (Hair et al., 2010). The summary of test results will be arranged in three different tables to facilitate the exposure. The table is used to describe hypotheses 1,2 , and 3 .

Hypothesis 1 states that work passion has a positive effect on work performance. The result of hypothesis test shows that the hypothesis is well supported. This means that the higher the work passion of employees the higher their work performance. Work passion represents a positive source of activity investment that leads to performance achievement (Astakhova \& Porter, 2015).
Someone with a high passion will love his job so that the job will become his inner call and life mission (Tucker, 2002). A person with a work passion will also think that work is a means of self-development (Astakhova \& Porter, 2015) leading him to the totality at work.

An auditor with full awaareness of passion will love the job and make the job as a means of self-development. On this basis, people with high passion will always try their best for their work and avoid failure at work (Vallerand et al., 2007). Therefore, the work performance will be good.

Hypothesis 2 states that work passion affects work performance with moderated meaningfulnes of work. The result of hypothesis test states that the hypothesis is well supported. Meaningfulness of work implicitly plays an important role in strengthening the work passion relationship to work performance. According to Michaelson et al. (2014) meaningfulness of work can facilitate the search for behavior and psychological experiences that impact prosocial. Individuals who achieve meaningfulness of work will generate positive outcomes for the organization (Geldenhuys, Profit, and Venter, 2014). Thus, it shows that the meaningfulness of work drives the employees to do the job with full of appreciation.

An auditor who has a meaningfulness of work perception will work with great appreciation, which raises the awareness of the love of work and indirectly increases the work performance. On the basis of meaningfulness of work the employee will further strengthen the work passion which highly correlates with work performance.

Hypothesis 3 states that work passion affects work performance with moderated P-O fit (Person Organization Fit). Hypothesis test results states that the hypothesis is not supported. Person-organization value fit is a match between the value held by the organization and the value held by the individual (Chatman, 1989). The study states that $\mathrm{P}-\mathrm{O}$ fit does not affect the strengthening of work passion and work performance relationships.

Tucker (2002) states that a person with a high passion will love his work so much that the work will be unique inner call and life mission for him. Based on the concept, it becomes apparent that the mismatch of value between the organization and the self ( $\mathrm{P}-\mathrm{O}$ fit) no longer becomes a stumbling block for 
one's self in working and laboring due to high passion awareness. A person with high passion awareness will not make the absence of $\mathrm{P}-\mathrm{O}$ fit as a constraint or problem at work.

An auditor who works with passion will no longer signify the importance of match of value of the self with the company, due to the great love of work and the desire to be able to actualize and develop his potential. Therefore, $\mathrm{P}-\mathrm{O}$ fit will not strengthen the work passion and work performance relationships.

\section{CONCLUSION}

This research is important in terms of theoretical implications as it increases knowledge related to work passion and work performance as well as factors that can strengthen the relationship of both. The research was done by way of exploring the psychological mechanisms linking work performance and work perormance, and supported by various proven theories to bridge between variables such as the Conservation resources theory underlying work passion and job performance.

The results of the research have also been able to provide new support related to work passion relationship to work performance despite its limitation. In addition, this research captures another picture related to the concept of work passion in Indonesia, since today there are many Indonesian youths whose work is driven by passion.

Work environment conditions are increasingly dynamic, which consequently often requires companies to frequently make changes. Based on the conducted research, the company should further explore employee passion. This is because passion will drive the employee to work wholeheartedly to improve his performance. Moreover, if employees are made aware of the meaningfulness of the work, they will raise their own motivation to do their best.

All in all, this study still comes up with several limitations. First, the preparation of further research should use triangulation method as an effort to enrich information and knowledge, for example by adding interviews, in addition to conducting surveys. This will certainly enrich the information presented in the study. Second, data retrieval in this research is conducted at a single point of time or crosssectional. In order to strengthen the results of hypothesis testing to see the antecedents and consequent work passions, it is suggested to use the longitudinal method for accuracy and a better alternative. Third, based on moderate regression results indicating unsupported result, it is recommended that further research explore the effect of interaction using other variables in order to develop the aspect of work passion.

\section{REFERENCES}

Abdillah, W. \& Hartono,J. (2011). Partial Least Square. Andi Yogyakarta: Yogyakarta

Aiken LS and West SG (1991) Multiple Regression: Testing and Interpreting Interactions. Newbury Park, CA: SAGE

Astakhova \& Porter (2015). Understanding The Work Passion-Performance Relationship: The Mediating Role Of Organizational Identification And Moderating Role Of Fit At Work. Human Relations 2015, Vol. 68(8) 1315-1346

Baron \& Kenny (1986). The Moderator-Mediator Variable Distinction in Social Psychological Research: Conceptual, Strategic, and Statistical Considerations. Journal of Personality and Social Psychology Vol. 51, No. 6, 1173-1182

Brayfield, A. and Crockett, W. (1955) Employee Attitudes and Employee Performance. Psychological Bulletin, 52, 396-424.

Cable DM and DeRue DS (2002) The Convergent And Discriminant Validity Of Subjective Fit Perceptions. Journal of Applied Psychology 87(5): 875-884.

Chatman, Jennifer (1989). Improving Interactional Organizational Research: A Model of Person-Organization Fit. Academy of Management Review, 1989, Vol. 14, No. 3, 333-349

Chien, Lawler, dan Uen (2010). PerformanceBased Pay, Procedural Justice And Job Performance For R\&D Professionals: Evidence From The Taiwanese HighTech Sector. The International Journal of Human Resource Management Volume 21, 2234-2242

Ferdinand, Augusty. (2006). Metode Penelitian Manajemen. BP Undip.Semarang

Forest J, Mageau GA, Sarrazin C and Morin ES (2010) 'Work Is My Passion': The Different Affective,Behavioral, And Cognitive Consequences Of Harmonious 
And Obsessive Passion Toward Work. Canadian Journal of Administrative Sciences 28(1): 27-40.

Ghozali, Imam. (2006). Aplikasi Analisi Multivariate dengan Program SPSS. BP Undip. Semarang

Greguras, G. J., \& Diefendorff, J. M. (2009). Different Fits Satisfy Different Needs: Linking Person-Environment Fit To Employee Attitudes And Performance Using Self Determination Theory. Journal of Applied Psychology, 94, 465-477.

Gudono.(2014). Analisis Data Multivariat. BPFE. Yogyakarta

Hair, J. F., Black, W. C., Babin, B. J., \& Anderson, R. E. (2010). Multivariate data analysis (7th ed.). Upper Saddle River, NJ: Prentice Hall

Hackman, J. R., \& Oldham, G. R. (1976). Motivation Through The Design Of Work: Test Of A Theory. Organizational Behavior and Human Performance, 16, 250-279.

Hobfoll, S. (1989). Conservation of Resources A New Attempt at Conceptualizing Stress. American Psychologist. Vol.4 No.3 ,513524

Hobfoll,S. (2001). The Influence of Culture, Community, and the Nested-Self in the Stress Process: Advancing Conservation of Resources Theory. Applied Psychology Volume 50, 337-421

Hobfoll, S. E., Johnson, R. J., Ennis, N., \& Jackson, A. P. (2003). Resource loss,resource gain, and emotional outcomes among inner city women. Journal of Personality and Social Psychology, 84, 632-643

Kristof, A.L (1996). Person-Organization Fit : An Integratif Review Of Its Conseptualizations, Measurement, And Implications. Personal Psychology. 49 (1)
Michaelson, C. (2009). Meaningful work and moral worth. Business and Professional Ethics Journal, 28(1-4), 27-48.

Muchinsky, P. M., \& Monohan, C. J. (1987). What Is Person-Environment Congruence? Supplementary Versus Complementary Models Of Fit. Journal of Vocational Behavior, 31, 268-277.

Podsakoff, P. M., \& MacKenzie, S. B. (1989). A Second Generation Measure Of Organizational Citizenship Behavior. Unpublished manuscript, Indiana University, Bloomington.

Srivastava, S. (2012). Workplace Passion As A Moderator For Workplace Deviant Behaviour-Job Satisfaction Relationship: A Comparative Study Between Public Sector And Privatesector Managers. Asia-Pacific Journal of Management Research and Innovation 8(4) 517-523

Steger, M. F., Frazier, P., Oishi, S., \& Kaler, M. (2006). The Meaning In Life Questionnaire: Assessing The Presence Of And Search For Meaning In Life. Journal of Counseling Psychology, 53, 80-93.

Vallerand, R. J., \& Houlfort, N. (2003). Passion at Work: Toward a New Conceptualization. In D. Skarlicki, S. Gilliland, \& D. Steiner (Eds.), Social issues in management: Vol. 3. Emerging perspectives of values in organizations (pp. 175-204). Greenwich, CT: Information Age Publishing

Yperen, N.W \& Hagedoorn. (2003). Do high job demands increase intrinsic motivation or fatigue or both? The role of job control and job social support. Academic Management Journal, Vol.46 339-346 